\title{
Integration property of a wedge-elliptic cone waverider with scramjet engine
}

\author{
H. Liu, F.M. Wang, L.W. Li, and Y.B. Geng \\ Institute of Mechanics, Chinese academy of Sciences, Beijing, China
}

\begin{abstract}
The hypersonic waverider forebody is designed in this paper. For the present waverider, the undersurface is carved out as a stream surface of a hypersonic inviscid flow field around wedge-elliptic cone, and the upper surface is assumed to be a freestream surface. A finitevolume code is used to generate the three-dimensional flow field. The leading edge is determined by satisfying the condition that the lip is situated at the intersection line of shocks.
\end{abstract}

\section{Introduction}

In the recent years, interest in all aspects of hypersonic flight has grown tremendously. For hypersonic vehicles with long-range missions, the fuel load becomes a sizeable percentage of the overweight. The lift-to-drag ratio (L/D) and specific fuel consumption become important factors in design of this class of aircraft. For a lifting aerodynamic body, it is well known that high maximum lift-to-drag ratios are very difficult to obtained at hypersonic speeds, due to the presence of strong shock waves (hence high wave drag) and massive viscous effects. This paper will address some of the issues involved in airframe and propulsion system integration. The research presented in this paper represents a preliminary assessment of a long-range cruise waverider. The waverider planform was chosen because it has low drag characteristics, reasonable volumetrics. Recent advances in high temperature materials and high thrust-to-weight ratio propulsion systems indicate that low hypersonic speed aircrafts are feasible.

To understand the present work, let us briefly review the general concept of waverider. In 1959, Nonweiler[1] proposed the idea of constructing a three-dimensional hypersonic vehicle from a know flow field. Noweiler chose the flow field behind a planar oblique shock wave to generate a class of vehicles with a caret-shaped cross-section and a delta platform. The shock wave is attached to the sharp leading edges at the design Mach number and hence no flow spillage takes place around the leading edge, the lift is high due to the high pressures behind a two-dimensional planar shock wave exerted on the low-surface of the vehicle. Because the body appears to be riding on the top of the attached shock wave, it is called a waverider. The current waveriders theoretically operate at higher L/D than other hypersonic configurations. The idea of generating a hypersonic vehicle from a known flow field may be extended from Nonweiler's construction to more complex flows. For example, a conical flow can be used[2]. The resulting class of "conicalflow" waveriders was first investigated by Jones et al[3]. Rasmussen et al[4][5], Cole and Zien[6], and Kim et al[7], represent further variations-designing waveriders from flows over cones and elliptic cylinders using small disturbance theory. Further these investigators used the calculus of variations to search for optimum waverider shapes. Bowcutt and Anderson[8][9] generated a series of conical-flow waveriders that were numerically optimized for maximum L/D.

Waverider airframes have been shown to be promising configurations for hypersonic vehicles. The aerodynamic benefits of waveriders are list in reference [10], and are discussed in detail in references [11]. Many previous works have been shown both computationally[12] and experimentally[13] to yield higher L/D ratios at their design point than other hypersonic airframe configurations. In addition, the waverider's L/D ratio has been shown 'computationally to remain highly at off-design hypersonic Mach number[14]. The waverider is also benefit to construct the configuration for scramjet integration. O'Neill and Lewis[15] had designed engine-airframe 
integrated vehicles based on waverider shapes "carved" from a conical flow field. These waveriders can provide the uniform flow field to the engine inlet, and the contained flow field on the undersurface yields no cross-flow.

The overall performances of both cruise and accelerator vehicle are affected by the uniformity of flow field of the engine inlet. Uniformity of mass flux, proper pressure and temperature are essential for effective combustion to occur. This pressure containment necessitates fewer compression ramps to produce proper pressure and temperature required for combustion of fuel within a short combustor. In present research, the desired scramjet inlet pressure and temperature are provided to the engines through a series of precompression ramps on the lower surface of the waveride forebody. A waverider shape was generated from a three-dimensional flow field. The flow field was created by a hypersonic flow past a wedge body with variety angle, which osculates with an elliptic cone satisfied the power-law of $3 / 4$. The waverider aerodynamic force is computed to exam the validation of this engine integration.

\section{Wedge-elliptic cone waverider}

Traditionally, waveriders have been generated with analytically defined flow field, such as planar wedge flows, conical flows, or flow fields that are easily computed. The advantage of using these types of generation body is that the flow field behind the shock can be readily calculated. However, such simple flow fields do have limitations when the requirements of waverider shape change from a simple high lifting body to a forebody designed for a hypersonic engine-airframe integrated cruise vehicle. The need of high $\mathrm{L} / \mathrm{D}$, proper inlet pressure and temperature for combustion, uniform flow at the inlet station, and good off-design performance, suggests that a more successful waverider might be constructed from a combination of different flow field. In this study, a wedge with the two given wedge angles is chosen to generate precompression surface satisfying the need of high-pressure inlet. A set of the elliptic cones, the minor axis of which is determined by the power law, is selected to construct a wedge-elliptic body.

\subsection{Generation flow field}

The first step in designing a waverider shape is defining the generating flow field. For an inviscid flow field in general, the governing equations are the Euler equations given below

$$
\begin{gathered}
\frac{\partial U}{\partial t}+\frac{\partial E}{\partial x}+\frac{\partial F}{\partial y}+\frac{\partial G}{\partial z}=0 \\
U=\left(\begin{array}{c}
\rho \\
\rho U \\
\rho v \\
\rho w \\
e
\end{array}\right) \quad E=\left(\begin{array}{c}
\rho u \\
\rho u^{2}+p \\
\rho v u \\
\rho w u \\
(e+p) u
\end{array}\right) \quad F=\left(\begin{array}{c}
\rho v \\
\rho u v \\
\rho v^{2}+p \\
\rho w v \\
(e+p) v]
\end{array}\right) G=\left(\begin{array}{c}
\rho w \\
\rho u w \\
\rho v w \\
\rho w^{2}+p \\
(e+p) w
\end{array}\right)
\end{gathered}
$$

where: $\rho$ is the density, $u, v$ and $w$ are velocities, $p$ is pressure, $e$ is total energy.

These equations are solved numerically using Non-oscillatory and Non-free-parameter dissipation finite-volume scheme. The wedge body used in this preliminary study has a width $40 \mathrm{~cm}$, length $230 \mathrm{~cm}$ and two wedge angle of $4^{\circ}$ and $4.5^{\circ}$ respectively. The first and second precompression surface is $120 \mathrm{~cm}$ and $110 \mathrm{~cm}$ respectively. The major axis of the elliptic is determined by the distance between the upper and lower surface of the wedge selected, and the minor axis is determined by power-low. The waverider shape was defined at freestream Mach number 6 with an attack angle $4^{\circ}$. The grid dimension was $140 \times 80 \times 40$ in the axial direction, circumferential direction and radial direction, respectively. Figure 1 shows the wedge-elliptic cone surface grids, the grids on a symmetrical plane and a spatial section at the location of axial station $\mathrm{x}=230$. Figure 2 gives the calculation pressure contours of this generation wedge-elliptic cone flow field. 


\subsection{Generation of leading edge shape}

Once the flow field is calculated, waverider shape can be "carved" out of the flow field. The leading edge curve is traced back along the streamlines of the flow field to generate the low surface of a waverider, as shown in Figure 3. Any particular undersurface is uniquely defined by the intersection of the flow streamsurface with the shock wave, as shown by the curve labeled "leading edge" in Fig.4. In particular, the location of the waverider apex is determined by satisfying the condition that the lip is situated at the intersection line of the shocks. In this paper, the leading edge curve is generated by intersection of the level surface with the shock wave, in order to provide uniform inlet properties.

\subsection{Streamline tracing}

As noted in the previous section, streamlines are traced from the leading edge, through the flow field, to create the waverider lower surface. For a steady flow field, traces and streamlines are coincident. The traces equations are:

$$
\frac{d x}{u}=\frac{d y}{v}=\frac{d z}{w}=d t
$$

where: $u, v, w$ are the velocities in the $x, y, z$ direction, respectively.

Let us exam figure 4 more closely. It is a front-view of the flow field, illustrating the wedge apex, and both the wedge-elliptic cone base and shock base at some arbitrary distance downstream of the wedge apex. Consider the curve selected before in this front-view, lying below the wedge apex, as shown by the curve labeled "leading edge". Now construe this curve as a trace on the wedge-elliptic cone shock wave itself, and visualize streamlines trailing downstream from this trace, the resulting stream surface is the waverider undersurface sketched in figure 3 . This curve lies entirely below the $\mathrm{x}-\mathrm{z}$ plane to ensure that the waverider undersurface is a compression surface. Also in Fig.4, note the curve labeled "trailing edge". This is the intersection of the particular streamsurface with the plane of the shock base, and it represents the bottom surface trailing edge of the waverider. This is the shape of the bottom of the waverider base.

\subsection{Free stream upper surface}

The generation of the waverider lower surface by streamline tracing has been described in the previous sections. The upper surface of waveriders, in most research work, is treated as a freestream

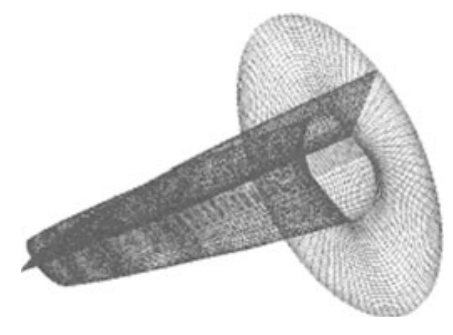

Fig. 1. Wedge-elliptic cone grid

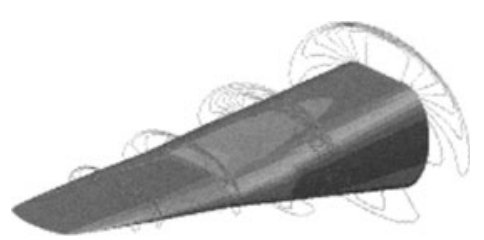

Fig. 2. Pressure contours of the generation body 
surface. In the present study, the upper surface is created by simply following the freestream back through the given leading curve to the base of the waverider. The pressure on this surface is the freestream pressure $p_{\infty}$.

Figure 5 shows the waverider generated from the indicated wedge-elliptical cone geometry. It gives the base, planform, and profile of perspective views of that waverider. Not that the waverider considered includes two differential wedge angle compressive surfaces, but inlet of the hypersonic vehicle in present also uses another two successive compression ramps in addition to this forebody compression. We discuss this in following section.

\section{Validation and discussion}

\subsection{Flow field around the waverider}

To validate the performance and the flow field created by the waverider generated by a wedgeelliptic cone, viscid flow field were calculated by using the code of "Fluent". The calculations were performed on an unstructured grid. The grid points were clustered near the body and the nose region.

Figure 6 shows the pressure contours at the waverider forebody surface, and it shows that the region of the high pressure locates about two-thirds of its span wide and the lower pressure region which equal to $p_{\infty}$ located at the top surface. This is in agreement with the principle of waverider designing. Figure 7 shows the oblique wave structure in symmetrical plane obviously, location of intersection between the first and second shock wave is at the distance of $210 \mathrm{~mm}$ from the nose of the waverider. This satisfies the condition of inlet lip.

\subsection{Conclusions}

Waverider created by unaxisymmetric flow field shows great promise as a basis for an engineairframe integrated vehicle. By providing the inlet with a high pressure uniform flow, this waverider satisfied the requirements of a forebody design the airframe-engine vehicle better than the traditional waverider based on conical flow field.

The configuration presented is an example of the first scramjet/integrated wedge-elliptic waverider with variable wedge angle. The waverider is beneficial to scramjet/integration for the following reasons, a) high pressure uniform properties, both spanwise and along the inlet height,
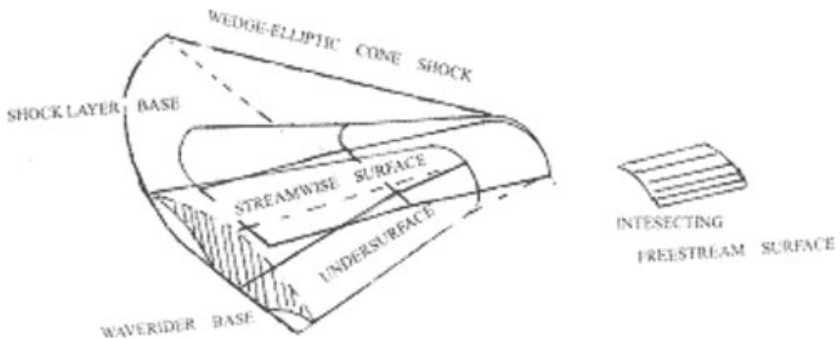

Fig. 3. Perspective view of a wedge-elliptic cone waverider and generating shock 
are provided; b) the waverider produces a high $\mathrm{L} / \mathrm{D}$ above 5.86 ; $\mathrm{c}$ ) an inverse design performance is made whereby the known flow field requirements of the engine lead to the appropriate vehicle geometry configuration.

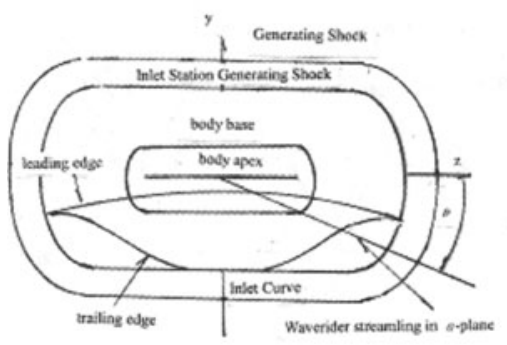

Fig. 4. Front view of a wedge- elliptic cone waverider with the generating body and shock

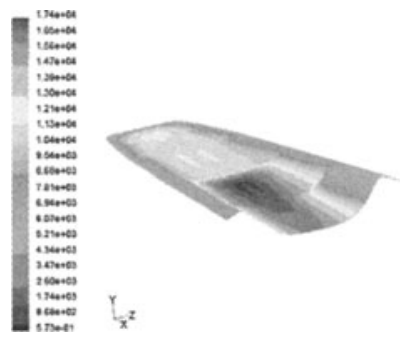

Fig. 6. Pressure contours on the waverider's surface
Fig. 5. Base, planform, profile and perspective view of the waverider

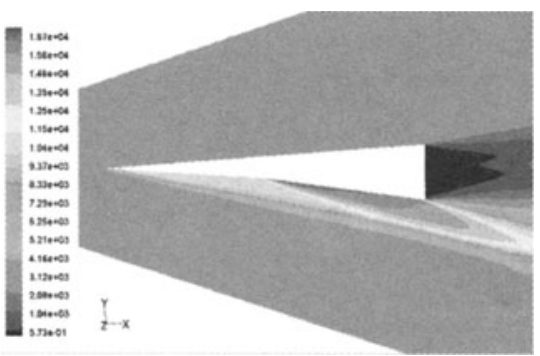

Fig. 7. Shock wave structure

\section{References}

1. T.R.F. Nonweiler: Aerodynamic problems of manned space vechile. Journal of the Royal Aeronautical Society 63, (1959)

2. J. Seddon and A. Spence: 'The Use of Known Flow Fields as an Approach to the Design of High Speed Aircraft'. In: Hypersonic Boundary Layers and Flow Field, AGARD CP NO. 30, May 1968, pp.10/1 - 10/21

3. J.G. Jones, K.C. Moore, J. Pike and P.L. Roe: A method for designing lifting configurations for high supersonic speeds, using axisymmetric flow field. Ingenieur-Archiv 37, 56

4. M.L. Rasmussen: Waverider configurations derived from inclined circular and elliptic cones. J. of Spacecraft and Rockers 17(6), 537 (1980) 
5. M.L. Rasmussen and L.W. Clement: Cone-derived waveriders with longitudinal curvature. AIAA Paper No. 84-2100 (1984)

6. J.D. Cole and T.F. Zien: A class of three-dimensional optimum hypersonic wings. AIAA Journal 7(2), 264 (1969)

7. B.S. Kim, M.L. Rasmussen and M.C. Jischke: Optimization of waverider configurations generated from axisymmetric conical flows. AIAA Paper 82-1299 (1982)

8. K.G. Bowcutt, J.D. Anderson and D.P. Capriotti: Viscous optimized hypersonic waveriders. AIAA Paper 87-0272 (1987)

9. K.G. Bowcutt, J.D. Anderson and D.P. Capriotti: 'Numberical Optimization of Conical Flow Waveriders Including Detailed Viscous Effects'. In: Aerodynamics of Hypersonic Lifting Vehicles, AGARD-CPP-428, March 1987, pp21/1-27/23

10. J.D.Anderson: A survey of modern reseach in hypersonics. AIAA Paper 84-1578 (1984)

11. L.H. Towend: Research and design for lifting reentry. Progress in Aerospace Sciences 18, 1 (1979)

12. S. Corda and J.D. Anderson: Viscous optimized waveriders designed from axisymmetric flow field. AIAA Paper 88-0369 (1988)

13. S. Bauer: 'Analysis of Two Viscous Optimized Waveriders'. In: First International Hypersonic Waverider Symposium, Univ. of Maryland, College Park, Oct. 1999

14. N. Takashim and M. J. Lewis: Nervier-stokes computation of a viscous optimized waverider. AIAA Paper 92-0305 (1992)

15. M.K.L. O'Neill and M.J. Lewis: Optimized scramjet integration on a waverider. AIAA Paper 91-1693 (1991)

16. M.J. Lewis and J. S. Chang: Joint jet-a/silane/hydrogen reaction mechanism. Journal of Propulsion and Power 6(2), 200 